\title{
The Critic as Former Child: A Personal Narrative
}

\author{
U.C. Knoepflmacher
}

I t has become a truth universally concealed that in purporting to talk about literary texts we are covertly talking about ourselves. We may successfully disguise our intense stake in some primary text by displaying our familiarity with Foucaultian or Lacanian formulations - or by relying on whatever other armature serves us best in parading our unchildish credentials as Highly Serious Readers. But such concealments have always been a bit harder to carry off for critics and teachers of those relational texts we place under the rubric of children's literature.

For some years now, I have been arguing, with mixed success, that in order to understand a children's classic, it may be helpful for us to know something about the actual childhood of the former boy or former girl who, as an adult. chose to write for a multiple audience of boys and girls and grownups. But if authors of children's books are - inevitably - ex-children, so too. of course, are the ever-more-numerous critics and teachers who try to explicate these books. If we can agree that the peculiar childhood and adolescence that shaped a Rudyard Kipling or a Frances Hodgson Burnett may have had a distinct bearing on their constructions of childhood and adolescence, should we not also be prepared to allow that the idiosyncrasies of a critic's own childhood and adolescence may affect his or her peculiar reconstructions of those constructions?

The circumstances of our early lives often determine the child-texts we choose to discuss as critics, and also affect the shape of our discussion. We may return as adults to images or narratives first processed in childhood: my current stake in Kipling, for example. may well go back to the Toomai film I saw as a six-year-old, and certainly to my subsequent reading, not too much later, of the first Jungle Book, perhaps in English, but more likely in a German edition that had made its way to South America. But the emotional configurations of our childhood also affect the nature of our engagement with child-texts we first encounter as grown ups: my strong investment in $A$ Little Princess, or my desire to flesh out intertextual relationships between Kipling and Burnett, is not based on any childhood reading. Instead. the hybridity of the Anglo-Indian Sara Crewe and of the wolf-boy Mowgli seem to speak to the displaced boy who still lives within me, a child-self still mesmerized by metamorphic fantasies that help vanquish loss and denigration. Princess Sara as well as Mary Lennox, Mowgli as well as Kim, thus belong to a clan of child-figures who are my special kin. They are the cousins of Jakob, the boy transformed into a stunted but resourceful dwarf Long Nose - whom I met long before Maurice Sendak and Doris Orgel introduced him to American readers: and of Wilbur, the helpless piglet who becomes a caring nurturer of spiderlings whom I met long after my American children absorbed Charlotte's Web.

Our textual choices are logical but highly arbitrary extensions of our subjectivity. When several reviewers of my recent study of Victorian child-texts rightly took me to task for excluding Kingsley's The Water-Babies, a work they, but not I, highly esteemed. I was reminded of F. R. Leavis's even more arbitrary placing of a Pole, an American, and a polyglot Englishwoman into a book he grandly called The Great Tradition of the English Novel . We all privilege texts that yield some sort of self-reflection, however faint or blurred or distorted or unrecognized or resisted and denied. Children's books often feature projection. Maybe, as a result, expositors of children's books find their own self-reflections a bit easier to acknowledge.

At least, so I hope. For I'd like to engage in some probing into my origins as a reader of three children's texts. I do not want what follows to become a self-indulgent and debased version of the Wordsworthian or egotistical sublime. Still, I shall move from the present into a few personal pasts in order to squeeze some meaning out of the randomly chosen Wordsworthian spots of time that I am eager to connect. Let me begin with a starting point that is quite recent and hence less hazy than the recollections which will then follow.

December 14, 2000. It is a Thursday, and I am in London, briskly pacing towards the new British Library. I am supposed to deliver a keynote lecture at the Bethnal Green Museum of Childhood on the next day. Everybody will be talking about $\mathrm{C}$. S. Lewis. for it is the fiftieth anniversary of the publication of The Lion, the Witch, and the Wardrobe. Yet I shatl be speaking about Burnett's $A$ Little Princess, having been asked to dwell on any 
late-Victorian or Edwardian antecedent to the first Narnia book. Eschewing logical choices by going to the works of George MacDonald or E. Nesbit, I shall perversely hold up Burnett's this-worldly, centrifugal text as a distinct alternative to Lewis's other-worldly, centripetal text. I do not expect wild applause from an audience of Narnia-devotees. But right now l am cheerfully walking towards the British Library, excited at the prospect of looking at the manuscript of Kipling's Just So Stories that is waiting for me

I take a different route from the one traversed on the day before, when there was barely time to renew my library card. Suddenly, looming out the brick wall to my left, I see a dark shape I quickly recognize. It is Anne Frank - at least her head and half of her upper torso are emerging from the brickwork. And before her, almost displacing the familiar sad face. is a soiled bucket, bespattered and grey, and hence in sharp contrast to the sleek. clean lines of the black iron sculpture. 1 read the inscription. It is meant to be uplifting: 'Anne Frank', it says, 'The Triumph of the Spirit'. But the effect on me is not at all uplifting. The demeaning bucket seems especially oppressive. Was Anne Frank assigned to some work brigade before her death? Did the starving child eat out of some bucket of slop? I try to remember. But, instead, what unexpectedly comes to mind is the mass-humiliation inflicted on Vienna's Jews: given brushes and buckets to remove placards, paint stains, and other detritus off the city's walls, all members of a community declared to be unclean were ordered to cleanse impurities with soap and water. My joyous anticipation of hours with Kipling's manuscript seems tarnished. What am I doing here in the streets of another grey European metropolis? Anne Frank was not allowed to grow up, to move beyond her arrested adolescence, to become a literature professor with the leisure to gloss over child-texts. Is this statue a portent. then, a grim check on my complacency, a reminder of the ephemeral nature of my pretensions? Yet as soon as I find myself ensconced in the library's manuscript room, I start to decode Kipling's tiny script. Anne Frank is forgotten. And so is the bucket. I sharpen my pencil and feverisily take pages of notes.

December 15, 2000. A day has passed. I deliver my lecture at the Museum of Childhood. As I heat the echoes of my own voice. I am struck by its obsessive insistence on the superior imagination of a displaced, starving child, Sara Crewe, the little girl in the attic. My carefully prepared emphasis-on the novel's multi-layered textual evolution, on its intertextual links, on its place in a tradition that goes back to Wordsworth and to the Brontës, and, finally, on the features that make it a foil for that other Edwardian attic text, C. S. Lewis's The Magician's Nephew (set in the Edwardian period though, of course, written in the 1950s) - now seems inconsequential, an intellectualized scaffolding for something that is more emotional and personal. And, as I mention the street-child who will be named Anne at the end of Burnett's novel, I recall the sadly smiling black statue of the day before. My narrative about doubles has ignored a major affinity. Anne Frank, I now see, is an unrescued Sara Crewe, torn away from her own attic refuge, from the protective eyrie of her own vibrant imagination. And only now do I remember, as I bring my anti-Narnia perorations to an acceptable close. that Anne's bucket had actually vanished when I emerged out the British Library after my three hours of play with Rudyard Kipling. What I had misread as an integral part of an artistic construct was merely a workman 's bucket placed, by sheer chance, before Anne Frank's sculpture. It was I, not the sculptor, who had endowed it with a significance that stemmed from my own buried associations as a Jewish child in Nazi Vienna.

Back in my hotel room, later that evening. I question my role in the Narnia proceedings. Why am I so much more attracted to Burnett's little girl in the attic than to Lewis's child-explorers? Why had I favourably contrasted the figure of Ram Dass, Sara's exotic Magician, not only to Uncle Andrew. Digory's uncaring Magician Uncle, but also to the royal Aslan Himself? Why had I insisted on contrasting the Romantic materiality of Burnett's text to the Christocentric immateriality of fables written in direct response to events that robbed Anne Frank and me of our European identities? Clearly, there were sub-texts here that I had not even begun to fathom. But I want to fall asleep now. Wide awake with jet-lag, I try 10 steer towards more soothing memories. I am in England. And so it seems natural to evoke an earlier English epiphany. It had been in Sussex. of all places, in Kipling's Sussex, over twenty years ago. when suffering from a late-night jet-lag almost as badly as right now, that I first saw my 
self-reflection in a dependent pig called Wilbur. My mind races backwards in time.

April 1977 (?) After my mother's death in 1972 , my Aunt Edith has become a parental surrogate, my last link to a dimly remembered family past in a Vienna that she and my dead mother - but neither my father nor I - have revisited. I had packed Charlotte's Web on a visit to my aunt's new lodgings in a Sussex condominium, for I had decided to add some more twentieth-century texts to the children's literature course I would be teaching in the coming Fall. My aunt and I had gone to a concert, eaten a hearty dinner, and talked animatedly about a great variety of subjects. 1 greatly admired this cultured, independent woman. Her musical knowledge was impressive: I had not known, until she pointed it out that evening. how a young Schubert had impishly twitted Beethoven in.his rearrangement of a phrase from the Choral Symphony. But now Aunt Edith was sleepy. And l was wide awake. So, after she settled me in a tiny guest bedroom on another floor, I pulled Charlotte's Web out of my bag and began to read.

I could not put the book down. Flaubert reputedly claimed that he was Emma Bovary, and George Eliot gravely pointed to her own forehead when asked who had been the 'original' for Mr. Casaubon in Middlemarch. To me, it was instantly clear that $I$ was Wilbur ('Wilbur, c'est $\left.m o i^{\prime}\right)$. It is an identification that still holds today as much as on that memorable night. Wilbur, of course, is no Huck Finn. Offered freedom, an opportunity to head out for the territories, he is betrayed by his orality, ignominiously recaptured by a bucket - not unlike that bucket in front of Anne Frank's statue - a bucket full of delicious slop. Independence is something that this innocent cannot manage. Wilbur is as dependent on others as I was when I came to the United States as a twenty-year-old, still unable to take a bus or to dial a phone. Wilbur moves from the protection of one surrogate mother to that of another, until reprieved. he can himself become a nurturer.

If I saw myself in Wilbur that night. I also identified my Aunt Edith with Charlotte. It is not often that someone comes along who can replace both a mother and a father. My college students idolize Charlotte as a wise adult. but are rather hard on Wilbur the child. I seduce them with my own buckets of siop by proving to them that $E$. B. White does indeed satirize the credulity of a consumer society for whom advertising has replaced religion; I can interest them in the religious iconography Garth Williams subtly introduces in his drawings; I can involve them in White's art of understatement and show them how his novel enacts the principles of The Elements of Style. But I cannot convince them that gluttonous Wilbut. whiny and immature, is more than just some pig, is indeed worthy of clever Charlotte's investment in him as a transmitter of her values. And so, he remains my secret double, a self-reflection I largely keep to myself.

There is room for just one further spot of time.

It was earlier in the 1970s, maybe in 1974, that I again confronted a text $\mathrm{l}$ had cherished first as a child and then as a late adolescent, the story of Zwerg Nase or Dwarf Long Nose. The odyssey of the boy who is abducted, deformed, and yet endowed with superior powers by an aged sorceress who stamps him with her own features meant much to me. Hauff's fairy tale. which is followed by the story of 'Abner the Jew Who Saw Nothing', another favourite of mine, appealed to a refugee child forced to see himself as an outsider. Wrested away from the secure world he had known, the twelve-year-old Jakob does not grow into adulthood after his seven years of servitude at the house of a magical mother-substitute. Just as Sara Crewe remains a prepubescent who must fit herself into a little girl's dress, so must Jakob be pressed, though nineteen, into the body of a tiny dwarf. And yet, with the help of another exile, as fragile as he, the resourceful boy manages to survive. I read the story to a girlfriend and her little sister when I returned to Bolivia in 1954, between my junior and senior years at Berkeley. Since neither of them spoke German. 1 translated it into Spanish as I read from the text I still seem to own.

Twenty years later. however, in 1974, I came across the 1960 Orgel/Sendak version of the story. I had joined a discussion group run by Ravenna Helson to talk about children's books. By pure coincidence, Dwarf Long Nose, a copy of which friends had given to my children. was to be the first selection for the group to discuss. I had expected to learn from others how to talk about child-texts. But to my amazement these others - besides Dr. Helson, 
a Jungian psychologist, there were people from history. anthropology, and literature - seemed to be genuinely interested in my own take on this - to me - so familiar story. Our next assignment was Higglety Pigglety Pop!, a text that was totally new to me. I was surprised to find that, once again. I seemed to have some insights to contribute. A few years later I had become confident enough to offer a children's literature course at Berkeley. It did not feature Dwarf Long Nose, nor did it yet include Charlotte's Web. And The Secret Garden rather than A Little Princess had been my Burnett choice. But when, on the first day of classes, 250 students instead of the thirty I had anticipated, circled Wheeler Hall, I felt as if 1 had been thrust into one of those transformational fantasies I had alway's cherished. The abducted Jakob turned into Dwarf Long Nose profited from a craft acquired during his liminal existence between childhood and maturity. 1 , too, had somehow profited from that inbetween condition.

Let me bring these reminiscences to a halt. I used to tell students in children 's literature classes that what all of us had in common was the retained identity of a former child reader. But that generalization turns out to be quite faulty. For the differing circumstances of our early readership of juvenile texts result in highly discrepant adult responses. And. what is more, the different circumstances of our early lives also make us react differentiy to those child-texts we belatedly encounter as aduits. By first reading American or English children's classics in German or in Spanish or, conversely, by reading English translations of texts I had originally read in German - I probably became more linguistically wary. Am I now better attuned to Twain's use of the vernacular in Huckleberry Finn because I was so greatly baffled, at age ten, by the unfamiliar Berlin dialect used by the German translator of an edition my parents had obtained from fellow-refugees in Bolivia? Did I perhaps read the text more carefully as a result? I remember being as frustrated by the alien dialect as I was by the fuzzy delineations of pen-and-ink illustrations that blurred yet cleverly leased me with the shapes of Huck. Jim. Dauphin. and Duke. I doggedly lingered on the drawings as much as on the verbal text in order to make sense out of a narrative l desperately wanted to decode. Huck and Jim. but not Tom Sawyer. soon joined the swelling ranks of my private band of outcast survivors.
C.S. Lewis's child characters were not among the chosen band. Despite much evidence to the contrary, I continue to regard The Lion, the Witch and the Wardrobe as a fable for young insiders. those who are merely asked to reexperience truths to which their wiser elders have already given a fully considered assent. As Lewis himself acknowledged. the book involves a transposition: 'What might Christ be like if there really were a world like Narnia and he chose to be incarnate and die and rise again in that world as he has actually done in ours?' (Letter to Mrs. Heck. 29 December 1958. quoted by H. Carpenter in The Inklings [Boston: Houghton Miffien Co., 1979, p. 223]). The question, although perhaps of greater interest to Christians than to Jews, is fascinating; but its execution seems better handled by Spenser, whom Lewis understands so well in The Allegory of Love. I thus admire the expositor of the adolescent Red Crosse Knight's temptations. fall and resurrection in Book One of The Faerie Queene much more than the creator of a religious translatio for children as well as for those adults who would be as little children. But my preference also remains idiosyncratic. The former refugee child seems to prefer books that stress the difficulties of passage, assimilation and conformity. I listened respectfully to the fine papers delivered at the Bethnal Green Museum of Childhood. Yet 1 was struck that the best of these (reprinted here) either treated the Narnia books as intricately 'adult' theological texts or chose to place Lewis among writers who remembered. perhaps more than he ever wanted to do so himself. the taste and texture of their former childhood and the pains of leaving that childhood behind. 


\section{REFERENCES}

Burnett, F.H. (1905) A Little Princess.

Burnett, F.H. (1911) The Secret Garden.

Carpenter. H. (1979) The Inklings

Hauff. W. (1827) Zwerg Nase.

Kingsley. C. (1863) The Water-Babies.

Kipling. R. (1894) The Jungle Book

Kipling. R. (1902) Just So Stories

Leavis, F.R. (1948) The Great Tradition.

Lewis. C.S. (1936) The Allegory of Love

Lewis. C.S. (1955) The Magician's Nephew.

Sendak. M. (1960) and D. Orgel, trans. Dwarf Long Nose

Sendak. M. (1967) Higglety, Pigglety, Pop!

Twain. M. (1884) The Adventures of Huckleberry Finn

White. E.B. (1952) Charlotte's Web.

\section{BIOGRAPHICAL NOTE}

U.C. Knoepflmacher, Paton Foundation Professor of Ancient and Modern Literature at Princeton University, is author of numerous articles and five books on Victorian literature, the most recent of which is Ventures into Childland: Victorians, Fairy Tales, and Femininity (1998). Among the four books he has co-edited are the 1992 edition (with Nina Auerbach) of fantasies by Victorian women writers, Forbidden Journeys, and the 1997 collection (with the late Mitzi Myers) of essays devoted to 'Cross-Writing ' and the Reconceptualizing of Children's Literature Studies. He has recently edited the Penguin editions of The Complete Fairy Tales of George MacDonald (1999) and Frances Hodgson Burnett's $A$ Little Princess (2002).

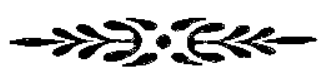

